Egyptian Journal of Rabbit Science, 25(1): 21 - 38(2015)

\title{
EVALUATING INTERMITTENT FLASHED LIGHT AS ECONOMICAL LIGHT SOURCE FOR RAISING NEW ZEALAND WHITE RABBITS
}

\author{
M. F. A. Farghly ${ }^{1}$ and H. Hamdon ${ }^{2}$ \\ ${ }^{1}$ Department of Poultry Production, Faculty of Agriculture, University of Assiut \\ (71516), Egypt. \\ ${ }^{2}$ Department of Animal and Poultry Production, Faculty of Agriculture, University \\ of Assiut, New Valley branch, Egypt \\ Email: farghly20002000@yahoo.com
}

The present investigation suggesting that light flashes can be used in improving the productive and reproductive performance of New Zealand White (NZW) rabbits and decreasing electricity consumption. Total of seventy two, weaned rabbits aged 4 weeks were randomly distributed into six experimental groups. The first group, the rabbits were subjected to $12 \mathrm{hrs}$ artificial light/day as a control (C). While, the second group (T1), rabbits were subjected tol2 hrs of biomittent artificial light (BAL) cycles/hour (15 AL min. $+15 \mathrm{D}$ min.). The third group (T2), rabbits were subjected to $12 \mathrm{hrs}$ of biomittent flashed light (BFL) cycles/hour (15 FL min. $+15 \mathrm{D}$ min.). The fourth group (T3), rabbits were subjected tol2 hrs of intermittent artificial light (IAL) cycles/day (3 hrs AL+ 3D hrs). The fifth group (T4), rabbits were subjected intermittent flashed light (IFL) cycles/day (3 hrs FL and 3 D hrs). The sixth group (T5), rabbits were subjected to 12 hrs of $(F L) / d a y$.

Based on the obtained results, significant $(P \leq 0.05)$ effects were observed in growth performance and dressed carcass of flashed light treated groups. Also, light flashes induced significant increases in sperm-cell concentration. While, no significant differences were existed in most semen traits and blood parameters values. Conception rate and reproductive index were significantly $(P \leq 0.05)$ improved in bio-intermittent flashed light treated groups than that in control and continuous flashed light treated groups. However, no significant differences were demonstrated in gestation period, litter size and bunny weight.

In conclusion, use of light flashes allowed a better growth performance without notable effects on plasma profile. Also, it becomes more beneficial for reproductive performance, especially when applied under intermittent flashed light. 
Furthermore, the flashed light schedules are easy to apply and low cost in rabbit farms as economical alternative light source under semi closed housing system according to economical efficiency.

Keywords: Flashed light, productive and reproductive performance, New Zealand Rabbits.

It is well recognized that the performance of rabbits is influenced by several environmental factors such as light. Light affects vision (feeding), physical activity, metabolic rate (digestion), and other physiological factors such as reproduction and hormonal status. The increasing difficulties with the high cost of electricity consumption in particular have brought about the need to evaluate other alternatives or methods to decrease electricity costs and or improve the performance. It has been described for a long time that rabbits are more active in darkness, their feed and water intake is higher than in light periods. However, rabbits were reared in total darkness do not show higher feed intake (Reyne et al., 1978; Jilge, 1993). A regular light-dark cycle plays an important role in regulating melatonin production. Melatonin is a hormone released during the dark hours of the day, which is involved in establishing circadian rhythms of several essential in various physiological and metabolic functions (Malpaux et al., 2001; Marai et al., 2002). From this viewpoint, using shorter or restricted light may be better for the rabbit welfare and performance, in addition it can be less expensive (Marai et al., 2007; Farghly and Abd El-Ati 2011; Farghly and Abdelnabi, 2014).

Lighting programs, which are easy to apply and are low cost, will be more efficient if the rabbits are in the same physiological state. The effect of light on the rabbits' production was analyzed by several authors (Mirabito et al., 1994; Maertens and Luzi, 1995; Arveux and Troislonches, 1995; Virág et al., 2000; Hoy and Selzer, 2003; Mahrose et al., 2010; Farghly 2011; Matics et al., 2012). There is another lighting program (module) called light flashes program which had studied by Farghly and Abd El-Ati (2011), Farghly (2011) and Farghly and Abdelnabi (2014) observing that using light flashes program was associated with better performance and less rectal temperature, which positively reflected on the immunity and health conditions of the rabbits with less costs. However, according our best understanding no author analyzed so far the effect of intermittent or biomittent light flashes on the rabbits' production.

Therefore, the objective of this study was to investigate if the productive and reproductive performance of NZW rabbits could be improved, when photoperiod is decreasing, by adopting intermittent or biomittent flashed light program and to avoid any undesirable effects with lowest costs under semi closed housing system in Assiut (Egypt). 


\section{MATERIALS AND METHODS}

The experimental work of the current study was conducted at rabbitary Research Unit, Poultry Production Department, Faculty of Agriculture, Assiut University, Assiut, Egypt. The experiment lasted during the period from September to April, where the environmental temperature mean ranged between $19.8{ }^{\circ} \mathrm{C}$ at night to $27.6{ }^{\circ} \mathrm{C}$ at midday while, relative humidity was from 42 to $66 \%$. Seventy two (4 weeks - old, unsexed) New Zealand White rabbits (NZW) were randomly, distributed into six treated groups to investigate the effect of intermittent flashed light on productive and reproductive performance as well as economical efficiency. Each experimental group involved 12 rabbits, with 3 replicates of 4 rabbits each. The first group, the rabbits were subjected to $12 \mathrm{hrs}$ artificial light/day as a control (C). While, the second group (T1), rabbits were subjected to $12 \mathrm{hrs}$ of biomittent artificial light (BAL) cycles/hour (15 AL min. + $15 \mathrm{D}$ min.). The third group (T2), rabbits were subjected to $12 \mathrm{hrs}$ of biomittent flashed light (BFL) cycles/hour (15 FL min. +15 D min.). The fourth group (T3), rabbits were subjected to $12 \mathrm{hrs}$ of intermittent artificial light (IAL) cycles/day (3 hrs AL+ 3D hrs). The fifth group (T4), rabbits were subjected intermittent flashed light (IFL) cycles/day (3 hrs FL and $3 \mathrm{D}$ hrs). The sixth group (T5), rabbits were subjected to $12 \mathrm{hrs}$ of (FL)/day. Light intensity measured at the middle of the cages ranged between 30-40 lux. using incandescent bulbs in all houses.

Rabbits were housed in semi-closed building and kept in individual galvanized wire cages $(60 \times 55 \times 40 \mathrm{~cm})$ provided with manual feeders and automatic stainless steel nipple drinkers. All sources of natural light were covered with heavy cotton black curtains and blackout plastic curtains which completely prevent any source of natural light. Healthy rabbits were maintained under the same environmental and managerial conditions. Clean fresh water was available for all rabbits by nipple drinker all time. All growing rabbits were fed ad libitum on grower commercial diet containing $2670 \mathrm{ME} / \mathrm{kcal}, 18.25 \% \mathrm{CP}$ and $11.17 \% \mathrm{CF}$ (weaning and up to sexual maturity), while the second (reproductive diet) containing $2460 \mathrm{ME} / \mathrm{kcal}$, $16.17 \% \mathrm{CP}$ and $13.30 \% \mathrm{CF}$ (sexual maturity and lasted till the end of experimental period.

During the experimental period, individual live body weight was recorded biweekly, also feed consumption $(\mathrm{g} / \mathrm{d})$ and feed conversion ratio $(\mathrm{g}$ feed/g gain) values were calculated. At the end of the growing period (16 weeks), 3 fasted rabbits from each group were randomly taken for slaughter to study carcass traits. Giblets weight (liver, kidney, heart) and carcass measurements were obtained and their relative pre-slaughter weights were 
calculated. At slaughter, blood samples were taken in two tubes, one contained EDTA and the other had no anticoagulant. Plasma total protein, albumin, globulin, albumin: globulin ratio, total lipids, AST and ALT were determined by enzymatic method using available commercial kits. Globulin was calculated by subtraction of Plasma albumin from total plasma protein.

Mating was carried out naturally. Each doe was transferred to the buck's cage to be mate (two services) and returned back to its cage after mating. Does pregnancy was checked after 10 days via the abdominal palpation. Does were re-mated again on the same day if the pregnancy test showed negative results. However, if the test was positive, females were allowed to give birth then mated again after 1 day from that date. The numbers of mating per conception, conception rate $(\%)$, litter size at birth and at weaning and gestation length (d) were recorded. Reproductive index (RI) was calculated as follow: (RI= Total litter size at birth $x$ Conception rate $\mathrm{x}$ Viability rate) for three parities.

Eighteen semen samples were collected at 10 am from all experimental bucks by using artificial vagina and a teaser and mature does. The ejaculate volume was recorded by using a graduated collection tube after removing the gel mass. The sperm concentration was evaluated by using haemocytometer. Hydrogen ion concentration $(\mathrm{pH})$ of semen was determined immediately after collection by using $\mathrm{pH}$ cooperative paper. Preweaning mortality rate from birth up to weaning age for bunnies was recorded daily. Morbidity corresponded to frequency of enteric disease or severe loss of weight. Health risk was the sum of morbidity and mortality (Farghly and Abdelnabi, 2014).

Economical efficiency (EE): Feed cost per rabbit was calculated by multiplying mean FC per rabbit by the cost of $1 \mathrm{~kg}$ of diet. Light cost per rabbit was calculated by multiplying mean electricity consumption per rabbit by the cost of $1 \mathrm{kw}$ of electricity. Rabbit price was calculated by multiplying mean rabbit weight by price of $1 \mathrm{~kg}$ of carcass for growing and number of kids for reproductive. Net revenue was calculated by subtracting rabbit price from feed and light costs. Economical efficiency (EE) was estimated by dividing net revenue by total costs.

\section{Statistical analyses:}

One Way Analyses of Variance (ANOVA) using general linear model (GLM) of SAS software (SAS Institute, 1996) statistically analyzed Data. The following model was used for analysis of variance:

$$
\mathbf{Y}_{\mathrm{ij}}=\boldsymbol{\mu}+\mathbf{T}_{\mathrm{i}}+\mathbf{e}_{\mathrm{ij}}
$$

Where: $\mathrm{Yij}=$ An observation, $\mu=$ Overall mean, $\mathrm{Ti}=$ Treatment effect $(\mathrm{i}=1,2, .$. $6)$, e $\mathrm{ij}=$ Experimental errors. 
Significant differences between treatment means were determined using Duncan's New Multiple Ranges- Test (Duncan, 1955).

\section{RESULTS AND DISCUSION}

\section{Growth performance:}

Data shown in Table (1) reveal that Body weight (BW) and body weight gain $(\mathrm{BWG})$ at 16 wks of age was significantly $(\mathrm{P} \leq 0.05)$ higher for rabbits exposed to intermittent flashed light than other treated groups and the control rabbits. The impact of intermittent flashed light on body weight and gain as proved in this study was supported by Farghly (2011) who found that $\mathrm{BW}$ and $\mathrm{BWG}$ of rabbits exposed to flashed light was significantly $(\mathrm{P} \leq 0.05)$ higher than those of control group. Growing rabbits do not really need continues light, but rearing under flashed light for one hour or more/day may be satisfy the young rabbit needs and do no harm. The increase in growth for rabbits reared under intermittent light flashes may be due to less activity when lights were switched off which associated with secretion of melatonin, which governs in various physiological systems, including the cardiopulmonary, excretory, thermoregulatory, behavioral, immune, and neuroendocrine systems in animals (Marai et al., 2002). These results were agreed with that of Theau-clement et al., (1995), Marai et al., (2004) and Farghly and Abd El-Ati (2011) who found that body weight of rabbits was significantly higher when exposed to short photoperiod or light flashes than long photoperiod or common light, this may be due to the decrease in the heat load that caused by exposure to lamps light radiation. However, Touitou et al., (1992); Szendro et al., (2004); Meshreky et al., (2005) and Rizzi and Chiericato (2008) found that light did not affect growth rate.

Daily feed intake and feed conversion ratio are presented in Table 1. The results exhibited no significant differences $(\mathrm{P}<0.05)$ in daily feed intake. However, significant differences $(\mathrm{P} \leq 0.05)$ among treatments were found in FCR at age 12-14 and 14-16 week-old. From the obtained data, the bio- intermittent flashed light treated groups had the highest improving effect on FCR compared with the control group and both was significantly $(\mathrm{P} \leq 0.05)$ higher than the control rabbits. It has been described for a long time that rabbits are more active in darkness, their feed intake is higher than in light periods. However, rabbits kept in total darkness do not show higher feed intake (Lebas et al., 1986). Daily feed intake was significantly lower for rabbits reared under short photoperiods than for those exposed to long photoperiod, which can be explained by light stimulation to the pineal function leading to 
increase in cortisol hormone through activation of the hypothalamic pituitaryadrenal axis and the consequent increase of plasma glucocorticoid concentrations 
(Christison and Johnson, 1972) and melatonin, which can affect FI, energy metabolism, and immune responses (Szendro et al., 2004). The authors Marai et al., (2004) and Farghly and Abd El-Ati (2011) found that rabbits exposed to long daylight were deleteriously affected than those exposed to short daylight in FI values. However, Reyne et al., (1978) found that increase a dark period leads to an increase of FI values. This improvement of FCR for rabbits in T4 and T5 may be mainly due to the insignificant decrease in FI value. Also, it may be due to either a reduction in physiological stress and energy expenditure which associated with shorter photoperiods or light flashes. These results are in agreement with previous reports of Szendro et al., (2004). In contrary, Meshreky et al., (2005); Rizzi and Chiericato (2008) and Farghly (2011) who, found that light did not affect feed intake and feed conversion ratio values.

\section{Carcass characteristics:}

Carcass characteristics data are presented in Table 2. Dressed and carcass weight percentages were significantly higher $(\mathrm{P} \leq 0.05)$ in biointermittent flashed light treated rabbits and control group compared with continues flashed light group. Also, liver percentages were significantly higher $(\mathrm{P} \leq 0.05)$ in flashed light treated rabbits compared with the control group. However, heart, kidney and fat percentages of all treatment groups were not significantly different $(\mathrm{P}<0.05)$. These results exhibited that the increasing in rabbit's dressed weight percentage due to increase body weight was pronounced with bio- intermittent flashed light treated rabbits. Similar results reported by Farghly and Abd El-Ati (2011) who, found that rabbits exposed to light flashes significantly affected dressed carcass and liver percentages. McKee et al., (2009) found that light had no affect on carcass defects. Jordan et al., (2008) reported that the percentages of carcass, liver of the rabbits kept under constant 12L: 12D were 54.37 and $3.04 \%$, respectively. The increase of marbling fat content could improve the eating quality of rabbit meat, which is low in fat and generally considered to be insufficiently tasty and juicy. Contrary, Lewis and Perry (1990) showed the intermittently illuminated hens had a lower fat content in the whole carcass than the conventionally illuminated rabbits (Pla, 2004; Meshreky et al., 2005; Das and Bardoloi, 2008). Also, Farghly (2011) found that light flashes did not affect carcass traits. 
Table 2: Effect of flashed light on carcass traits of growing New Zealand White rabbits.

\begin{tabular}{lcccccc}
\hline \multirow{2}{*}{ Traits } & \multicolumn{7}{c}{ Treatment groups } \\
\cline { 2 - 7 } Pre-slaughter weight & $\mathbf{C}$ & T1 & T2 & T3 & T4 & T5 \\
\hline LBW, g & $2236.0 \pm$ & $2196.0 \pm$ & $2320.0 \pm$ & $2260.0 \pm$ & $2330.0 \pm$ & $2288.0 \pm$ \\
\multirow{2}{*}{ Heart, \% } & $0.29 \pm$ & $0.30 \pm$ & $0.30 \pm$ & $0.29 \pm$ & $0.30 \pm$ & $0.31 \pm$ \\
& 0.01 & 0.01 & 0.01 & 0.02 & 0.01 & 0.01 \\
\hline \multirow{2}{*}{ Liver, \% } & $2.70 \pm$ & $2.84 \pm$ & $2.98 \pm$ & $2.85 \pm$ & $3.00 \pm$ & $2.98 \pm$ \\
& $0.05^{\mathrm{b}}$ & $0.11^{\mathrm{ab}}$ & $0.06^{\mathrm{a}}$ & $0.12^{\mathrm{ab}}$ & $0.05^{\mathrm{a}}$ & $0.11^{\mathrm{a}}$ \\
\hline \multirow{2}{*}{ Kidney, \% } & $0.77 \pm$ & $0.78 \pm$ & $0.75 \pm$ & $0.76 \pm$ & $0.74 \pm$ & $0.79 \pm$ \\
& 0.01 & 0.02 & 0.02 & 0.01 & 0.02 & 0.01 \\
\hline \multirow{2}{*}{ Whole fat, \% } & $3.01 \pm$ & $3.00 \pm$ & $2.94 \pm$ & $3.14 \pm$ & $2.89 \pm$ & $2.92 \pm$ \\
& 0.06 & 0.08 & 0.08 & 0.05 & 0.08 & 0.10 \\
\hline \multirow{2}{*}{ Dressed weight, \% } & $61.42 \pm$ & $61.29 \pm$ & $61.32 \pm$ & $61.85 \pm$ & $61.90 \pm$ & $60.83 \pm$ \\
and $^{*}$ Means within each row for each division & $0.52^{\mathrm{a}}$ & $0.75^{\mathrm{ab}}$ & $0.75^{\mathrm{ab}}$ & $0.56^{\mathrm{a}}$ & $0.66^{\mathrm{a}}$ & $0.66^{\mathrm{b}}$ \\
\hline
\end{tabular}

\section{Blood parameters:}

Metabolic profile data presented in Table 3. No significant effect $(\mathrm{P}>0.05)$ was observed for total proteins, total lipids, globulin, AST and ALT of growing rabbits among all groups. Exposure to suitable light is associated with potential welfare benefits, including lower physiological stress, improved immune response, increased sleep and increased overall activity. The previous results are in agreement with Mahrose, et al., (2010) and Farghly and Abdelnabi (2014) who found that the physiological body reactions of bucks (plasma total protein, albumin, globulin, AST and ALT) did not significantly affected by photoperiods. Also, no significant effect $(\mathrm{P}>0.05)$ was observed for total proteins, total lipids and globulin of growing rabbits among all treated flashed light groups.

In addition, the rabbits exposed to light flashes had significantly $(\mathrm{P} \leq 0.05)$ lower AST and ALT values than those of the control group (Farghly, 2011). The present results are in contrary to those reported by Marai et al., (2007) and (2004) who found that long daylight (16L:8D) had deleterious effect on blood metabolites (albumin and glucose) and liver function (AST, ALT) in rabbits compared to short daylight (8L:16D). Similar results were reported by Habeeb et al., (1997) and EL-masry et al., (1994).

\section{Semen characteristics of bucks treated:}

No significant differences in the values of semen color and semen $\mathrm{pH}$ were found among all groups (Table 4). However, the bio-mittent common light and flashed light treated groups had significantly $(\mathrm{P} \leq 0.05)$ higher of semen concentration compared with the control group. 
Table 3: Effect of flashed light on blood constituents of growing New Zealand White rabbits.

\begin{tabular}{lcccccc}
\hline \multirow{2}{*}{ Traits } & \multicolumn{7}{c}{ Treatment groups } \\
\cline { 2 - 7 } & $\mathbf{C}$ & $\mathbf{T 1}$ & $\mathbf{T 2}$ & $\mathbf{T 3}$ & $\mathbf{T 4}$ & T5 \\
\hline \multirow{2}{*}{ Total proteins (mg/dl) } & $6.89 \pm$ & $7.00 \pm$ & $7.05 \pm$ & $6.94 \pm$ & $7.03 \pm$ & $7.10 \pm$ \\
& 0.08 & 0.10 & 0.02 & 0.11 & 0.04 & 0.08 \\
\hline \multirow{2}{*}{ Total lipids (g/dl) } & $2.90 \pm$ & $2.93 \pm$ & $3.00 \pm$ & $3.04 \pm$ & $3.00 \pm$ & $2.96 \pm$ \\
& 0.10 & 0.08 & 0.11 & 0.12 & 0.10 & 0.06 \\
\hline \multirow{2}{*}{ Globulin (mg/dl) } & $2.90 \pm$ & $2.92 \pm$ & $2.95 \pm$ & $2.94 \pm$ & $2.93 \pm$ & $3.00 \pm$ \\
& 0.08 & 0.10 & 0.04 & 0.03 & 0.05 & 0.10 \\
\hline \multirow{2}{*}{ Albumin (mg/dl) } & $4.00 \pm$ & $4.08 \pm$ & $4.05 \pm$ & $4.00 \pm$ & $4.10 \pm$ & $4.10 \pm$ \\
& 0.10 & 0.09 & 0.10 & 0.05 & 0.11 & 0.10 \\
\hline \multirow{2}{*}{ Albumin: globulin ratio } & $1.38 \pm$ & $1.40 \pm$ & $1.37 \pm$ & $1.36 \pm$ & $1.40 \pm$ & $1.37 \pm$ \\
& 0.05 & 0.02 & 0.03 & 0.04 & 0.03 & 0.05 \\
\hline \multirow{2}{*}{ AST U/I } & $27.38 \pm$ & $25.49 \pm$ & $25.68 \pm$ & $26.14 \pm$ & $25.62 \pm$ & $27.14 \pm$ \\
& 0.5 & 0.7 & 0.6 & 0.8 & 0.6 & 0.9 \\
\hline \multirow{2}{*}{ ALT U/I } & $25.69 \pm$ & $24.00 \pm$ & $25.28 \pm$ & $24.00 \pm$ & $25.27 \pm$ & $25.75 \pm$ \\
& 0.8 & 0.5 & 0.7 & 0.4 & 0.8 & 0.6 \\
\hline a and Means within each & row for each division with no common & superscripts \\
different (P $\leq 0.05)$. & \multicolumn{7}{c}{ significantly } \\
& & & & &
\end{tabular}

Table 4: Effect of flashed light on semen characteristics of New Zealand White rabbits.

\begin{tabular}{lcccccc}
\hline \multirow{2}{*}{ Traits } & \multicolumn{7}{c}{ Treatment groups } \\
\cline { 2 - 7 } & $\mathbf{C}$ & $\mathbf{T 1}$ & $\mathbf{T 2}$ & $\mathbf{T 3}$ & $\mathbf{T 4}$ & $\mathbf{T 5}$ \\
\hline \multirow{2}{*}{ Semen color (1-3) } & $1.34 \pm$ & $1.33 \pm$ & $1.30 \pm$ & $1.30 \pm$ & $1.29 \pm$ & $1.34 \pm$ \\
& 0.08 & 0.09 & 0.12 & 0.08 & 0.12 & 0.16 \\
\hline \multirow{2}{*}{ Semen volume (ml) } & $0.75 \pm$ & $0.76 \pm$ & $0.80 \pm$ & $0.79 \pm$ & $0.80 \pm$ & $0.77 \pm$ \\
& 0.10 & 0.10 & 0.06 & 0.04 & 0.06 & 0.10 \\
\hline \multirow{2}{*}{ Semen pH } & $7.60 \pm$ & $7.56 \pm$ & $7.62 \pm$ & $7.59 \pm$ & $7.62 \pm$ & $7.55 \pm$ \\
& 0.11 & 0.06 & 0.10 & 0.10 & 0.08 & 0.06 \\
\hline Sperm-cell concentration & $240.2 \pm$ & $242.4 \pm$ & $253.9 \pm$ & $248.3 \pm$ & $254.0 \pm$ & $252.4 \pm$ \\
$(\mathbf{1 0} / \mathbf{m l})$ & $4.9^{\mathrm{b}}$ & $4.6^{\mathrm{b}}$ & $3.9^{\mathrm{a}}$ & $3.9^{\mathrm{ab}}$ & $5.0^{\mathrm{a}}$ & $5.2^{\mathrm{a}}$ \\
\hline a and $\mathrm{b}$ Means within each & row for each division with no common & superscripts are & significantly \\
different $(\mathrm{P} \leq 0.05)$. & & & & &
\end{tabular}

The important photo-dependent hormone is the pineal melatonin, which plays an important role in the neuroendocrine control of reproductive cycle. Melatonin secretion is higher in dark (short day) period and lower in light (long day) period (Boyd, 1986; Bonanno et al., 2000). If a buck is not provided with light exposure at least for 8 to 12 hours, its spermatogenesis will be hampered. Improving the values of semen concentration under flashed light in the present study may be due that the rabbits in nature are nocturnal animals, and they prefer the night time to show their most daily normal activity. Similar results were reported by Abd Elhakeam et al., (1992), Mahrose, et al., (2010) and Farghly and Abdelnabi (2014) who, found that 
semen volume and concentration were significantly $(\mathrm{P} \leq 0.01)$ improved with short photoperiods than the long photoperiods. On the other hand, TheauClément et al., (1995), Marai et al., (2002) and Mousa-Balabel and Mohamed (2011) reported that exposure of rabbits to long days improved the quantity and quality of spermatozoa present in the ejaculates in comparison to those collected in rabbits exposed to short day light. Farghly and Abdelnabi (2014) found that light flashes did not affect semen $\mathrm{pH}$ and semen color values.

\section{Reproductive parameters of does treated:}

Results presented in Table 5. Does exposed to intermittent common or flashed light exhibited significantly $(\mathrm{P} \leq 0.05)$ higher conception rate and reproductive index than those exposed to biomittent or continuous flashed light. However, no significant differences in the values of litter size, bunny weight, gestation length and viability rate of bunnies. A breeding does will require at least $6 \mathrm{hrs}$ light exposure for its sexual performance and fertility. Litter size at birth in rabbits contributes to the expression of the reproductive capacity of the doe, depends on ovulation rate (Udała and Błaszczyk, 1999). A certain level of light is a signal to start or stop the synthesis of melatonin, which controls the synthesis and secretion of the hypothalamus hormones which regulate the secretion of pituitary hormones responsible for ovulation, prolactin levels and immune systemactivity (Udała and Błaszczyk, 1999; Goldman, 2001; Malpaux et al., 2001). Similar results were found for kindling rate, litter size, weight and viability when applying intermittent photoperiods or flashed light compared to continuous lighting (Uzcategui and Johnston, 1992; Arveux and Troislouches, 1995; Virág, et al., 2000; Farghly and Abdelnabi, 2014), while Hoy and Selzer (2003) found an increased frequency of twice-a-day nursing when applying intermittent photoperiods. On the other hand, no differences were found between the continuous and discontinuous lighting programmes on reproductive performance (Shafei, et al., 1984; Theau-Clément and Mercier, 2004; Szendrö et al., 2004; Matics, et al., 2012).

Studies approaching photoperiod manipulation in rabbit farms have generally shown a significant improvement in receptivity and fertility of does when the daylight length was increased (Harris et al., 1982; Boyd, 1986; Lebas et al., 1986; Theau-Clement et al., 1990 and Uzcategui and Johnson, 1992; Mirabito et al., 1994; Maertens and Luzi, 1995; Felska et al., 2002; Theau-Clément and Mercier, 2004; Theau-Clément et al., 2008; Gerencsér et al., 2010). Mousa-Balabel and Mohamed (2011) found that exposure of rabbits to long improved doe's sexual receptivity, litter size and weight at birth, while, gestation period and pre-weaning mortality percentage decreased. This may be due to increase the milk production of does because of the light stimulation modifying the number and duration of nursing events, which increased when the dark period was shorter (Gerencsér et al., 2008). Mahrose et al., (2010) 
EVALUATING INTERMITTENT FLASHED LIGHT FOR RAISING RABBITS

31

Table 5: Effect of flashed light on reproductive performance of does New Zealand White rabbits.

\begin{tabular}{|c|c|c|c|c|c|c|c|}
\hline \multirow{2}{*}{\multicolumn{2}{|c|}{ Traits }} & \multicolumn{6}{|c|}{ Treatment groups } \\
\hline & & $\mathbf{C}$ & T1 & T2 & T3 & T4 & T5 \\
\hline \multicolumn{2}{|c|}{ Conception rate (\%) } & $\begin{array}{l}80.6 \pm \\
3.8^{\mathrm{ab}}\end{array}$ & $\begin{array}{l}72.8 \pm \\
2.8^{\mathrm{b}}\end{array}$ & $\begin{array}{l}81.0 \pm \\
5.0^{\mathrm{ab}}\end{array}$ & $\begin{array}{c}86.4 \pm \\
4.3^{\mathrm{a}}\end{array}$ & $\begin{array}{c}86.8 \pm \\
4.1^{\mathrm{a}}\end{array}$ & $\begin{array}{l}73.2 \pm \\
2.9^{\mathrm{b}}\end{array}$ \\
\hline \multirow{2}{*}{\multicolumn{2}{|c|}{ Gestation length (day) }} & $31.2 \pm$ & $31.0 \pm$ & $31.0 \pm$ & $30.9 \pm$ & $30.7 \pm$ & $31.0 \pm$ \\
\hline & & 0.29 & 0.34 & 0.18 & 0.42 & 0.31 & 0.19 \\
\hline \multirow{2}{*}{$\begin{array}{l}\text { Litter size } \\
\text { (kids) at }\end{array}$} & Birth & $\begin{array}{c}6.44 \pm \\
0.52\end{array}$ & $\begin{array}{c}5.99 \pm \\
0.45\end{array}$ & $\begin{array}{c}6.60 \pm \\
0.49\end{array}$ & $\begin{array}{c}6.68 \pm \\
0.38\end{array}$ & $\begin{array}{c}6.67 \pm \\
0.40\end{array}$ & $\begin{array}{c}6.01 \pm \\
0.39\end{array}$ \\
\hline & 4 weeks & $\begin{array}{c}5.62 \pm \\
0.28\end{array}$ & $\begin{array}{c}5.22 \pm \\
0.19\end{array}$ & $\begin{array}{c}5.82 \pm \\
0.29\end{array}$ & $\begin{array}{c}5.91 \pm \\
0.25\end{array}$ & $\begin{array}{c}6.00 \pm \\
0.29\end{array}$ & $\begin{array}{c}5.19 \pm \\
0.22\end{array}$ \\
\hline \multirow{2}{*}{$\begin{array}{l}\text { Bunny weight } \\
\text { (g) at }\end{array}$} & Birth & $\begin{array}{c}58.6 \pm \\
1.88 \\
\end{array}$ & $\begin{array}{c}60.4 \pm \\
2.72 \\
\end{array}$ & $\begin{array}{l}57.4 \pm \\
2.92 \\
\end{array}$ & $\begin{array}{c}59.0 \pm \\
2.60\end{array}$ & $\begin{array}{c}58.5 \pm \\
3.11 \\
\end{array}$ & $\begin{array}{c}57.2 \pm \\
3.00\end{array}$ \\
\hline & 4 weeks & $\begin{array}{c}468.8 \pm \\
5.22\end{array}$ & $\begin{array}{l}480.9 \pm \\
8.75\end{array}$ & $\begin{array}{c}468.8 \pm \\
6.82\end{array}$ & $\begin{array}{r}478 \pm \\
10.0\end{array}$ & $\begin{array}{c}490.2 \pm \\
9.22 \\
\end{array}$ & $\begin{array}{c}459.8 \pm \\
6.74 \\
\end{array}$ \\
\hline \multicolumn{2}{|l|}{$\begin{array}{l}\text { Viability rate for } \\
\text { bunnies }(\%)\end{array}$} & $\begin{array}{c}87.3 \pm \\
2.11\end{array}$ & $\begin{array}{l}87.1 \pm \\
2.66\end{array}$ & $\begin{array}{c}88.2 \pm \\
4.22\end{array}$ & $\begin{array}{c}88.5 \pm \\
2.6\end{array}$ & $\begin{array}{c}89.6 \pm \\
3.94\end{array}$ & $\begin{array}{c}86.4 \pm \\
2.84\end{array}$ \\
\hline \multicolumn{2}{|c|}{ Reproductive index/doe } & $\begin{array}{l}4.53 \pm \\
0.24^{\mathrm{ab}}\end{array}$ & $\begin{array}{l}3.80 \pm \\
0.31^{\mathrm{b}}\end{array}$ & $\begin{array}{l}4.71 \pm \\
0.19^{\mathrm{ab}}\end{array}$ & $\begin{array}{l}5.11 \pm \\
0.22^{\mathrm{a}}\end{array}$ & $\begin{array}{l}5.21 \pm \\
0.18^{\mathrm{a}}\end{array}$ & $\begin{array}{l}3.80 \pm \\
0.15^{\mathrm{b}}\end{array}$ \\
\hline
\end{tabular}

found that conception rate, litter size, viability and calculated milk yield from birth to 21 days weaning were significantly $(\mathrm{P} \leq 0.05)$ lowered with the increase in photoperiods. Also, Mady et al., (1989) recommended longer darkness period to improve reproductive efficiency of does. Jensen (1980), El-Boghdady et al., (1992) and Farghly and Abdelnabi (2014) found insignificant effects of photoperiods on litter size at birth and gestation period.

\section{Health problems:}

Health problems data are presented in Table 6. The increased mortality in the rabbits reared under constant lighting may be due to less immunity or increased physiological stress. The double dark-light change might disturb the does, leading to slightly higher mortality in this group. These results are in agreement with Lebas et al., (1986), Szendro et al., (2004) and Farghly and Abd El-Ati (2011). Szendro et al., (2004) found that mortality was lower in the intermittent photoperiods compared to continuous lighting groups. In general, longer dark periods were associated with lower mortality. A review of studies that examined the effects of photoperiod on immune function showed that short photoperiod enhances immune function in a variety of species (Nelson and Demas, 1996). Light should not be switched on or off very suddenly since this may make the rabbit to leap here and there due to fear leading to fracture and other injuries. Using long photoperiods decreased the pre-weaning mortality rate among kits, which can be explained by the improved nursing behavior (Gerencsér et al., 
Table 6: Effect of flashed light on health problems of New Zealand White rabbits.

\begin{tabular}{lcccccc}
\hline \multirow{2}{*}{ Traits } & \multicolumn{7}{c}{ Treatment groups } \\
\cline { 2 - 7 } & C & T1 & T2 & T3 & T4 & T5 \\
\hline Morbidity, \% & 16.67 & 16.67 & 16.67 & 8.33 & 0.00 & 16.67 \\
\hline Mortality (adult), \% & 16.67 & 16.67 & 8.33 & 8.33 & 8.33 & 25.00 \\
\hline Health risk, \% & 33.34 & 33.34 & 25.00 & 16.67 & 8.33 & 41.67 \\
\hline No significant differences were observed (P>0.05). & & & &
\end{tabular}

2008). Farghly and Abdelnabi (2014) found insignificant effects of photoperiods on health risk and mortality rate.

Economical efficiency (EE):

Results in Table 7, indicate that the intermittent and/or flashed light treated rabbits had the highest economical efficiency as compared to control group. The economical efficiency of the T2, T3, T4 and T5 groups exceeded the control group (C) by $9.3,13.4,22.2$ and $10.4 \%$, respectively, during the growing period. However, T4 group had the best economical efficiency (118.85), then T2 and T3 groups (112.7 and 112.5), then T5 group (99.8) and the last one was the T1 group (92.1) during the reproductive period. Similar results were reported by Farghly and Abd El-Ati (2011) and Farghly and Abdelnabi (2014).

Finally, from an economic point of view, the flashed light schedules are cheap and easy to apply and can be used as biostimulation to improve the productive and reproductive performance of New Zealand White rabbits.

Conclusively: application of light flashes is beneficial to rabbit producers and intermittent flashed light is optimal for satisfying the physiological requirements of New Zealand White rabbits during growing and reproductive periods, under semi closed housing system.

\section{REFERENCES}

Abd Elhakeam, A.A., Abd El-Moty, A.K.I., El-Boghdady, A. H. and Hassanein, H.H. (1992). Some physical characteristics of rabbit semen as affected by breed, lighting systems and ejaculation sequences. Egyptian Journal of Rabbit Science, 2(1): 37 - 47.

Arveux, P. and Troislouches, G. (1995). Un programme lumineux discontinu stimule les lapines. Cuniculture, 121: 5-8.

Bonanno, A.; Alabiso, M.; Di Grigoli A., Alicata M.L. and Montalbano, L. (2000). Effect of a 48-hour doe-litter separation on performance of free or controlled nursing rabbit does, 7th World Rabbit Congress, Valencia, 2000, Section Reproduction and Reproductive Physiology, pp. 97-103. 
EVALUATING INTERMITTENT FLASHED LIGHT FOR RAISING RABBITS 33 
Boyd, I. L. (1986). Effect of daylength on the breeding season in male rabbit. Mamm. Rev., 16: 125-130.

Christison, G. I., Johnson, H. D. (1972). Cortisol turnover in heatstressed cows. J. Anim. Sci. 53: 1005-1010.

Das, S.k. and Bardoloi, R. K. (2008). Study on the factors affecting carcass traits of broiler rabbits in eastern Himalayan region of India. World Rabbit Sci., 16: 107 - 110.

Duncan, D.B. (1955). Multiple Range and Multiple F tests. Biometrics, 11:1-42.

El-Boghdady, A. H.; Abd El-Moty, A.K.I.; Abd Elhakeam, A.A. and Hassanein, H.H. (1992). Effect of lighting systems and breed on productive and reproductive performance of female rabbits. Egyptian Journal of Rabbit Science, 2(1): 23 - 36.

El-Masry, K.A.; A.S. Nasr and Kamal T.H. (1994). Influences of season and dietary supplementation with selenium and vitamin E or Zinc on some blood constituents and semen quality of New Zealand White rabbit males. J. World Rabbit Sci. , 2: 79-86.

Farghly, M. F. A. and M. A. Abdelnabi (2014). Effect of light flashes on reproductive performance of New Zealand White rabbits (Abstract). Accepted in $7^{\text {th }}$ International Poultry Conference, 3 - 6 November 2014, Ain Soukhna, Red Sea, Egypt.

Farghly, M. F. A. and M. N. Abd El-Ati, (2011). Effect of light flashes on growth performance, carcass characteristics and chemical composition of meat in New Zealand white rabbits. Egyptian J. Anim. Prod., 48:55-67.

Farghly, M. F. A., (2011). Using light flashes programme as a tool to avoid the hot weather effect on growth performance of New Zealand white rabbits. Egypt. Poult. Sci., 31:437-451.

Felska, L.; M. Brzozowski and E. Rzewucka (2002). Reproduction performance of chinchilla in relation to cage level and light intensity level. Zeszyty Naukowe Przegladu Hodowlanego, 64: 97-102.

Gerencsér Zs., Matics Zs., Nagy I., Biró-Németh E., Radnai I., Szendrő Zs. (2010). A termékenyítés elött megnövelt megvilágítás hatása az anyanyulak termelésére. Magyar Állatorvosok Lapja, 132, 647-650.

Gerencsér, Zs.; Matics, Zs.; Nagy, I.; Princz, Z.; Orova, Z.; BiróNémeth, E.; Radnai, I. and Szendri, Zs. (2008). Effect of lighting program on the nursing behavior of rabbit does. 9th World Rabbit Congress, June 10-13, Verona, Italy, 1177-1181 pp.

Goldman, B. D., (2001). Mammalian photoperiodic system: Formal properties and neuroendocrine mechanisms of photoperiodic time measurement. J. of Biol. Rhythms, 16:283-301. 
Habeeb, A. A. M.; I.F.M. Marai, A.M. El-Maghawry and A.E. Gad, (1997). Growing rabbits as affected by salinity in drinking water under winter and hot summer conditions of Egypt. Egypt. J. Rabbit Sci. , 72: 81-94.

Harris, D. J.; Cheeke, P.R. and Patton, N. W. (1982). Effect of diet, light and breeding schedule on rabbit performance. Proc. West. Sect. Amer. Soc. Anim. Sci., 33: 190.

Hoy, St. and Selzer, D. (2003). Frequency and time of nursing in wild and domestic rabbits housed outdoors in free range. World Rabbit Sci., 10: 77-84. doi: 10.4995/wrs.2002.479.

Jensen, N.E. (1980). The rabbit experiment station 1979. Progeny tests, feeding trails, lighting programme, Beretning Fra Statens. Husdyrbrugs Forsog, No. 496, pp 24 (Nutri. Abst and Rev. , 51, No. 9, pp 652.).

Jilge B. (1993). The ontogeny of circadian rhythms in the rabbit. J. Biol. Rhythms, 8: 247-260.

Jordan, D.; Gorjanc, G.; Kermauner, A. and Štuhec, I. (2008). Wooden sticks as environmental enrichment: effect on fattening and carcass traits of individually housed growing rabbits. World Rabbit Sci., 16: $237-243$.

Lebas, F.; Coudert, P.; Rouvier, R. and Rochambeau, H. (1986). The rabbit; husbandry, health and production. FAO Animal Production and Health Series, No 21

Lewis, P.D, and Perry, D.P. (1990). Effect of a $6 \mathrm{~h}$ increase in photoperiod at 17 weeks of age on feed intake, growth rate, carcass composition and age at sexual maturity. Br. Poult. Sci., 30:966-967.

Mady, M.E.; Khalifa, R.M. and El-Alamy, M. A. (1989). Effect of light regime and Eltroxine on the response of female rabbits to coitus. Egyptian Journal of Applied Sciences, 4 (4): 120 - 125.

Maertens, L. and F. Luzi, (1995). Effect of diluent and storage time of rabbit semen on the fertility of does reared under two different lighting schedule. World Rabbit Sci., 3: 57-61.

Mahrose, Kh. M.; Abd El-Monem, U.M. and Peris, S. I. (2010). Effects of photoperiod and mating or semen collection times on the performance of does and bucks of New Zealand White rabbits under hot climatic conditions of Egypt. The $6^{\text {th }}$ Inter. Con. on Rabbit Prod. in Hot Clim., Assuit, Egypt, pp: 503-520 .

Malpaux, B.; M. Migaud; H. Tricoire and P. Chemineau, (2001). Biology of mammalian photoperiodism and the critical role of the pineal gland and melatonin. J. Biol. Rhythms, 16:336-347. 
Marai I. F. M., Haeeb A. A. M, Gad A. E. (2004). Growth performance traits and the physiological background of young doe rabbits as affected by climatic conditions and lighting regime, under sub-tropical conditions of Egypt. Proceedings 8th World Rabbit Congress, September 7-10, 2004, Puebla, Mexico, 288-297.

Marai I.F.M.; A.A.M Haeeb and A.E.Gad, (2007). Biological functions in young pregnant rabbit does as affected by heat stress and lighting regime under subtropical conditions of Egypt. Tropical and Subtropical Agroeco systems, 7:165 - 176.

Marai, I.F.M., A.A.M. Habeeb and A.E., Gad, (2002). Rabbits productive, reproductive and physiological performance traits as affected by heat stress: a review. J. of Livest. Prod. Sci., 78, 71-90.

Matics Zs.*, Gerencsér Zs., Radnai I., Mikó A., Nagy I., Szendrő Zs. (2012). Effect of different lighting schedules (161:8d or 121:6d) on reproductive performance of rabbit does. Proceedings 10 World Rabbit Congress, September 3 - 6, 2012-Sharm El- Sheikh, Egypt, $319-323$.

McKee, N.A., R.J. Lien, J.B. Hess, S.F. Bilgili and McKee, S.R. (2009). Effect of light intensity and handling during rearing on broiler breast meat characteristics. Inter. J. of Poult. Sci., 8:1028-1033.

Meshreky, S. Z.; Gad S. A. and Arafa M. M. (2005). Growth performance, carcass treat, physiological response and economical efficiency of baladi red, v-line rabbits and their cross-under Egyptian environmental condition. $4^{\text {th }}$ Inter. Con. on Rabbit Prod. In Hot Clim, Sharm El-Sheikh Egypt, 197-210.

Mirabito L., Galliot P., Souchet C. (1994). Effet de l'utilisation de la PMSG et de la modiication de la photopériode sur les performances de reproduction de la lapine. In Proc.: Gémes Journ. Rech. Cunicole, La Rochelle, I: 155-161.

Mousa-Balabel TM. and Mohamed RA. (2011). Effect of different photoperiods and melatonin treatment on rabbit reproductive performance. Veterinary Quarterly, 31(4):165-71.

NRC (1977). National Research Council: Nutrient Requirements of Rabbits. $2^{\text {nd }}$ Revised Edition, National Academy of Sciences, Washington, DC. USA.

Nelson, R. J., and Demas, G. E. (1996). Seasonal changes in immune function. Quarterly Rev. Biol. 71:511-548.

Pla, M.; Pascual, M. and Ariño, B. (2004). Protein, fat and moisture content of retail cuts of rabbit meat evaluated with the nirs methodology. World Rabbit Sci., 12: 149 - 158. 
Reyne, Y.; Prud'hon, M.; Debicki, A.M. and Goussopoulos, J. (1978): Caractéristiques des consommations d'aliments solide et liquide chez la Lapine gestante puis allaitante nourrie ad libitum. Ann. Zootech., 27 (2): 211-223.

Rizzi, C. and Chiericato, G.M. (2008). Effect of environmental conditions on productive and physiological responses in growing rabbits. 9th World Rabbit Congress, June 10-13, Verona, Italy;1233-1237.

SAS (1996). SAS Procedures Guide. Version 6. 12 Edition. SAS Institute INC. Cary, NC, USA.

Shafie, M.M.; Kamar, G.A.R.; Borady, A.M. and Hassanein, A.M. (1984). Reproductive performance of Giza rabbit does under different natural and artificial environmental conditions. Egyptian Journal of Animal Production, 24: 167 - 174.

Szendro, ZS.; Biró-németh, E.; Radnai, I.; Metzger, SZ.; Princz, Z.; Gerencsér, ZS. (2004). The effect of daily lighting program on the performance of growing rabbits. Proceedings 8th World Rabbit Congress, September 7-10, 2004 - Puebla, Mexico; 1168-1171.

Theau-Clément, M.; Poujardieu, B.; Bellercaud, J. (1990). Influence des traitements lumineux, modes de reproduction et états physiologiques sur la productivité de lapines multipares. In Proc.: 5es Journées de la Recherche Cunicole, Paris, Tome 1 comm. 7.

Theau-Clément, M. and Mercier, P. (2004). Influence of lighting programmes on the productivity of rabbit does of two genetic types. In: Proc. 8th World Rabbit Congress, September, Puebla, Mexico, pp: 358-363.

Theau-Clement, M., N. Michel, J. Esparbie and G. Bolet, (1995). Effect of artificial photoperiods on sexual behaviour and sperm output in the rabbit. Anim. Sci., 60: 143-149.

Theau-Clément, M.; Malpaux, B.; Lamothe, E.; Milcent, N.; Juin, H. and Bodin, L. (2008). Influence of photoperiod on the sexual behaviour of non-lactating rabbit does: Preliminary results. 9th World Rabbit Congress, June 10-13, Verona - Italy.

Touitou Y., Benoit O., Foret J., Aguirre A., Bogdan A., Clodore M., Touitou C. (1992). Effects of a two hour early awakening and of bright light exposure on plasma patterns of cortisol, melatonin, prolactin and testosterone in man. Acta Endocrinology, 6: 201-205.

Udala, J. and B. Blaszczyk, (1999). Selected mechanisms regulating the course of reproduction processes in sheep and goats. Medycyna Weterynaryjna, 55: 733-736. 
Uzcategui M.E. and Johnston N.P. (1992). The effects of 10, 12 and 14 hour continuous and intermittent photoperiods on the reproductive performance of female rabbits. J. Appl. Rabbit Res., 15: 553-559.

Virag, G., Z. Papp, P. Rafai, L. Jakab and A. Kenessey, (2000). Effect of an intermittent lighting schedule on doe and suckling rabbit's performance. World Rabbit Sci., 8: 477-481.

\section{تقييم إضاءة الوميض المتقطع كمصدر إضاءة اقتصادي لتربيةأرانب

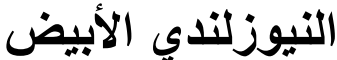

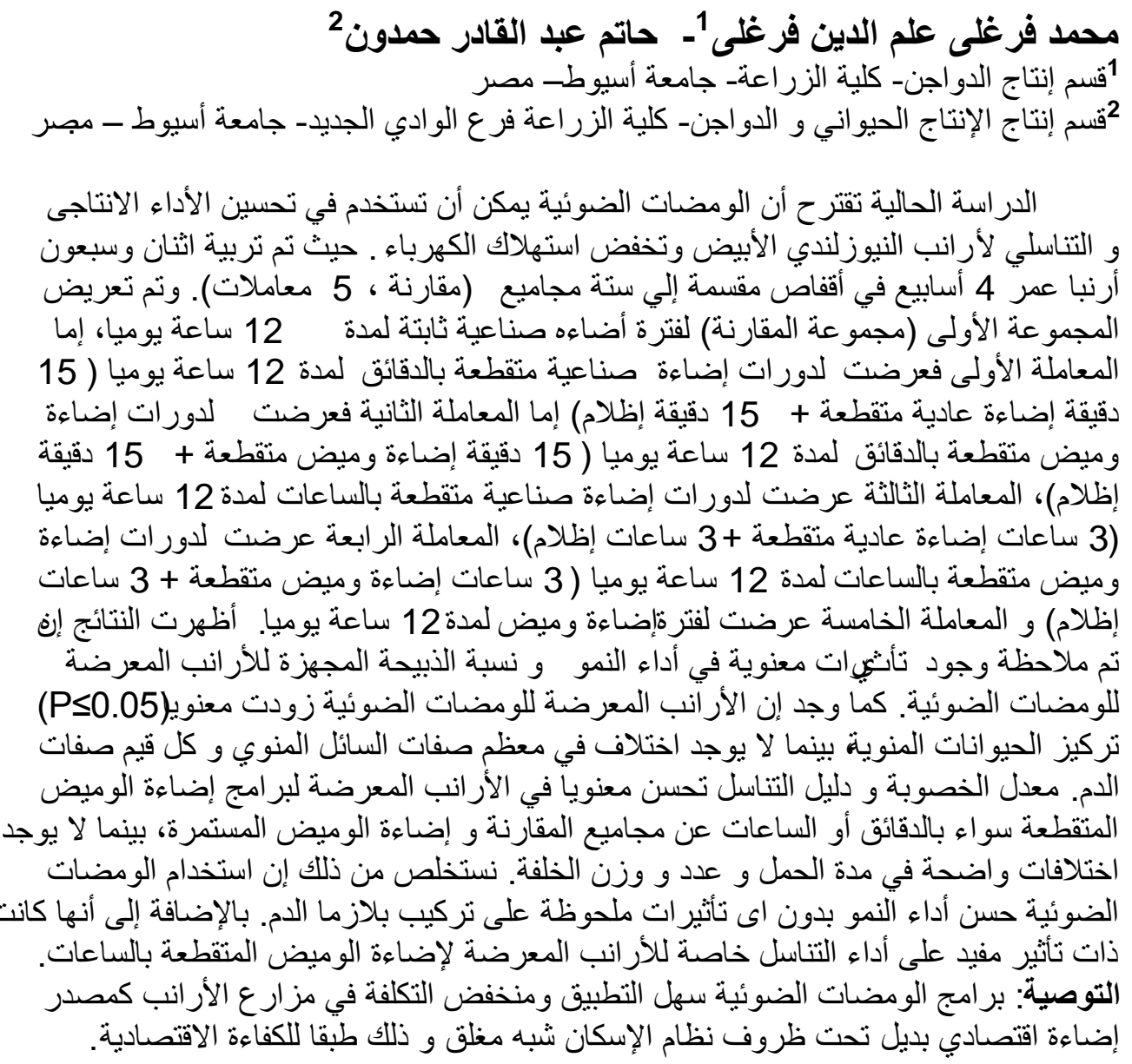

